Article

\title{
Forest Certification Perspectives in the Wood Products Supply Chain in Virginia, U.S.A.
}

\author{
John F. Munsell ${ }^{1}$, Adrian Ares ${ }^{1, *}$, Scott M. Barrett ${ }^{1}$, Brian H. Bond ${ }^{2}$ and Jennifer L. Gagnon ${ }^{1}$ \\ 1 Department of Forest Resources and Environmental Conservation, Virginia Tech, \\ Blacksburg, VA 24061, USA; jfmunsel@vt.edu (J.F.M.); sbarrett@vt.edu (S.M.B.); jgagnon@vt.edu (J.L.G.) \\ 2 Department of Sustainable Biomaterials, Virginia Tech, Blacksburg, VA 24061, USA; bbond@vt.edu \\ * Correspondence: aresa@vt.edu; Tel.: +1-540-629-5875
}

Academic Editor: Fred Cubbage

Received: 30 August 2017; Accepted: 18 September 2017; Published: 26 September 2017

\begin{abstract}
Participation among private forest owners, logging contractors, and wood products manufacturers in the forest certification sector remains low. Those that enroll are mainly large-acreage owners and specialized manufacturers. Little is known about certification perspectives across the supply chain and how they relate. Comparing what owners, contractors, and manufacturers think about certification would increase insight regarding sector growth. In this study, 2741 private forest owners, logging contractors, and wood products manufacturers in Virginia, U.S.A. were surveyed about their beliefs regarding the impact of certification on economic opportunities and image and the extent to which they think it positively affects the forestry sector and understand how to certify forestland. Co-orientation was used to map alignment and predictions between respondents. Owner and contractor responses were similar and predictions about each other mostly accurate, but manufacturer responses and predictions were largely incongruent. Manufacturers generally aligned more so with contractors than owners but contractors identified slightly more with owners. Owners and contractors shared perspectives and a discernable identity, whereas manufacturers viewed certification in a less positive light. Implications for participation in forest certification focus largely on interrelationships of actor perspectives regardless of scale and emphasize the roles each can play in the forest certification sector.
\end{abstract}

Keywords: sustainable forestry; private forest owners; logging contractors; wood products manufacturers; co-orientation

\section{Introduction}

Forest certification was developed in the early 1990s to curtail tropical deforestation through verified use of sustainable forest management [1]. Certification systems generally are market-based, non-regulatory, and focused on forests, operations and products, and associated businesses and communities [2,3]. Certified raw material is accounted for or tracked using chain-of-custody, and certified products typically are labeled. Consumption of certified wood products has grown slowly among regular market customers, but demand among green builders, renewable energy industries, and retail corporations has increased in recent years [4-7].

In the United States of America (U.S.A.), there are several forest certification systems (e.g., Sustainable Forestry Initiative; Forest Stewardship Council; American Tree Farm System). It is estimated, however, that only $12.9 \%$ of the 303.7 million acres (122.9 million ha) of U.S.A. forestland is certified [8]. Results of several studies indicate that most private forest owners and many logging businesses and wood products manufacturers are not aware of or do not see benefits in forest certification [6,9-12]. In 2013, 92\% of family forest owners with more than 10 acres (4 ha) in 
Virginia were slightly or not familiar with forest certification, and only $3.5 \%$ of the land belonging to this groups was certified [13].

Whether and why private forest owners participate in forest certification is thought to be affected by lack of awareness, costs, uncertainty, and incompatibility [14-17]. When institutional stakeholders and owners of large tracts of forestland certify it is typically for financial reasons, whereas family forest owners do so for intrinsic purposes [18]. According to the National Woodland Owner Survey (NWOS), little more than $10 \%$ of family forest owners are aware of forest certification [19], and even when they were, most of them did not understand it and many could not afford to enroll $[17,20]$.

At the same time, harvesting in certified forests can affect the operational strategy of logging contractors because they must adhere to associated standards and track harvested fiber [21]. Increasing such requirements for loggers may cause profit margins to narrow, but the overall effect of certification is potentially intermittent given most working tracts are not certified and many manufacturers do not regularly trade in certified raw material [12]. Those manufacturers that depend on certified raw material are often large and highly specialized, dealing only with forest owners and contractors that are able to consistently source large volumes in specific form $[9,22]$.

Growth in the certified wood products sector in the U.S.A. will require increased participation among smaller supply chain actors [17]. The potential to improve forestry operations through certification is significant [23] but transparency, conformity, eligibility, administration, and lack of awareness are barriers $[15,17,24,25]$ and there are many questions about the enduring viability of forest certification and uncertainty regarding its effects on long-term output and costs [26]. An uptick in demand for certified sustainable products and accompanying market share and branding could change the situation, but this is possible only insofar as supply is available and a substantial base of informed and motivated consumers exists [22,27].

Forest certification is a form of corporate social responsibility in its response to public interest in sustainable wood products $[28,29]$. It helps the forestry sector validate management, brand sustainable products, and potentially improve market access and price points. However, forest owners, logging contractors, and wood products manufacturers have unique entrepreneurial characteristics and marketplace perspectives, which can affect perspectives on socially responsible market behavior and, hence, the growth of the forest certification supply chain. Logging contractors run capital-intensive businesses with a stressful operational environment and narrow profit margins. Forest owners often focus on diverse objectives such as economic security and direct income as well as non-market aspects such as recreation, nature conservation, and aesthetics. Wood products manufacturers respond to trends in consumer demand and can postpone consumption in hard economic times leading to inventory retention, workforce suspension, and product substitution.

This paper reports on a study that measured and compared how owners, contractors, and manufacturers view forest certification and each other in order to better understand the attitudinal interrelationships among these supply chain actors. A mail survey was used to collect responses to questions about forest certification across all three groups. The survey also collected predictions by one group about the responses of another (e.g., owners predict contractor responses) and self-reporting on the degree to which one group identifies with another (i.e., the extent to which one group shares an identity with another).

Relevant topics for use in survey design were identified based on the literature and addressed issues pertaining to the economic benefits of forest certification, its effect on the image of supply chain actors among the general public, its impact on the forestry sector, and comprehension of the general mechanics of certification. Measurements of shared identity focused on forest sustainability and co-orientation was used to study whether and how responses and predictions line up among each group. Research hypotheses were that: (1) owner, contractor, and manufacturer perspectives about forest certification are aligned; (2) counterpart predictions between groups are accurate; (3) predictions by one group about another are similar to their own response; and (4) groups identify with each other in terms of forest sustainability. 
Improving entrepreneurial networking among owners, contractors, and manufacturers could benefit forest certification [30], though doing so will require trust, reciprocity, and shared orientation because the strength of social relationships between supply chain actors is greater when values and objectives are shared [31,32]. Networking in the wood products supply chain hinges to a degree on the sense of similarity among actors, but this may only go so far if disagreement and uncertainty exists between groups. Socially responsible firms consider not only their strategic and competitive orientation, but also the orientation of counterpart stakeholders [33]. More research is needed regarding the influence of micro-level behavioral processes on the progress and prospects of socially responsible behavior in the marketplace [34], which has direct implications for the forest certification sector.

Co-orientation is a relationship between two or more groups of people toward something of mutual relevance, importance, or interest [35-37]. Co-orientation analysis addresses three communication states: agreement, accuracy, and congruency. It is determined by comparing intergroup agreement about a common issue and assessing the accuracy and congruency of predictions made by one group about another regarding the shared matter $[36,38]$. Agreement is when group perspectives about something are the same (i.e., oriented). Accuracy is when one group correctly predicts another group's perspective. Congruency is when one group's prediction of another group's perspective is the same as their own. Different combinations of communication states may lead to true consensus, false consensus, false conflict, or dissensus [39,40].

Co-orientation models have been examined in fields such as community views on ecological restoration [41] environmental decision-making [36], and wildlife management [42]. In Germany, a co-orientation approach was used to examine perceptions on sustainability among forest owners and end consumers who conducted self-evaluation and evaluation of the other group's points of view [43]. The two parties disagreed (i.e., in an actual state of dissensus) on the social responsibility dimension of sustainable forestry. In regards to the environmental dimension, forest owners believed they agreed with the end users when, in reality, that was not the case (i.e., in false consensus). In this study, we used the co-orientation approach to examine views on forest certification with an eye toward forest products benefits and innovation between different supply chain stakeholders.

Alignment between forest owners, logging contractors, and wood products manufacturers is desirable for entrepreneurial networking $[44,45]$. A contractor and manufacturer may agree on something but inaccurately believe the other thinks differently (i.e., false consensus). Thus, the perspective of one participant (e.g., manufacturers) in the supply-chain impacts the extent to which counterparts (e.g., forest owners) are able or willing to interact and function. Additionally, when estimates about more than one counterpart group are offered (e.g., logging contractor perspectives about manufacturers and forest owners), the alignment of each prediction points to differences in the views pertaining to multiple counterparts. Other cases may involve participants with limited or no opinion where networking seems improbable even when they identify with each other.

\section{Materials and Methods}

The study was carried out in Virginia, U.S.A. which stretches from the Atlantic coast to the Appalachian Mountains encompassing 27.4 million acres $\left(110,785 \mathrm{~km}^{2}\right)$ of coastal plain, piedmont hill, and mountainous landscapes (Figure 1). Mail surveys were used to collect data from forest owners, logging contractors, and wood products manufacturers. Surveys were tailored for each type of respondent, but all contained sets of interrelated co-orientation items and the same description of forest certification so that all respondents were oriented to standardized baseline concepts. Surveys were reviewed by expert panels and refined before distribution. Changes included minor editorial adjustments to enhance clarity. 


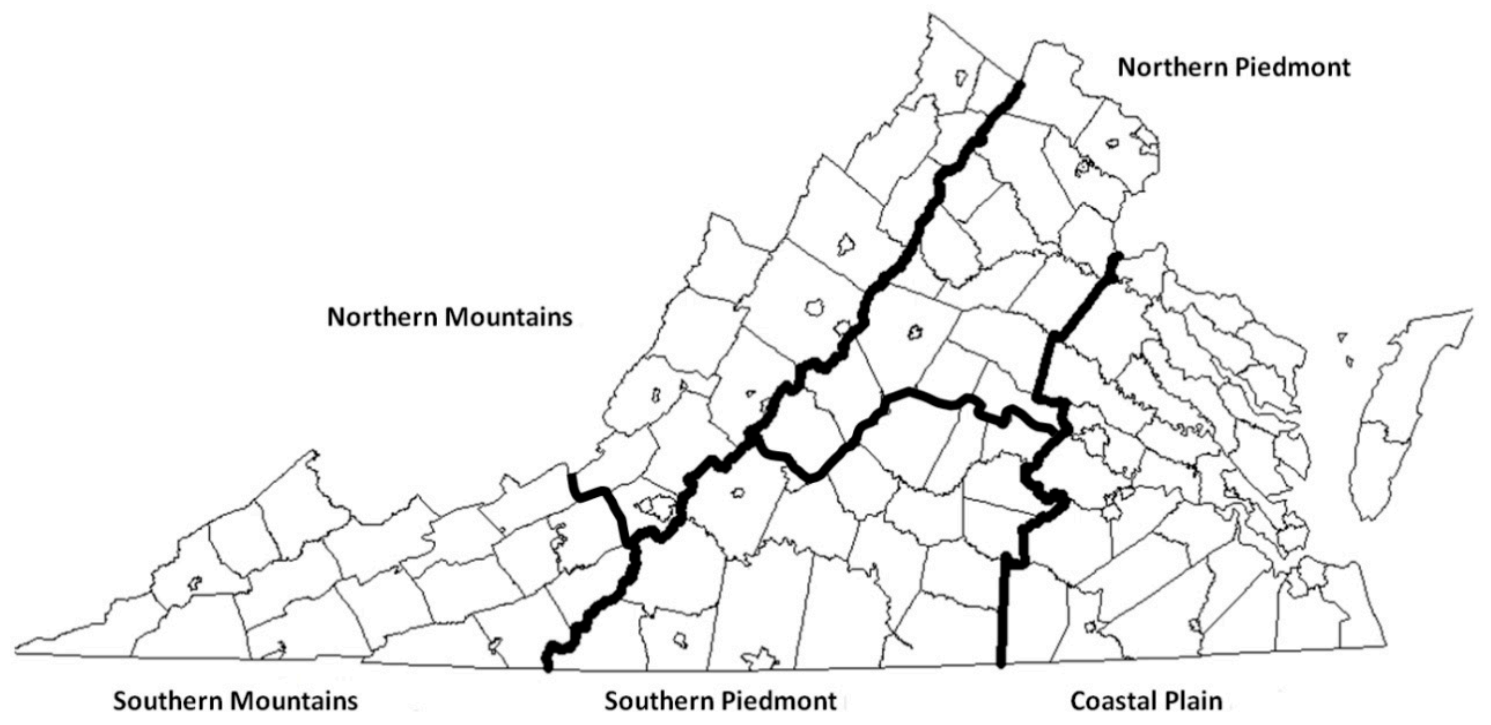

Figure 1. Map of the 95 counties in the Commonwealth of Virginia, U.S.A. and five U.S. Department of Agriculture's Forest Service regions (Northern Mountains, Southern Mountains, Northern Piedmont, Southern Piedmont, and Coastal Plain).

Five-point scales were developed for this research and used to measure whether respondents believe: (1) forest certification provides economic advantages; (2) forest certification improves their image; (3) forest certification positively impacts the forestry sector; and (4) they generally understand what is required to certify forests. Also, included were a series of eight 5-point items which asked respondents to predict supply chain counterpart responses to these four measurements. A 3-point uni-polar item ranging from "not at all like me" to "a lot like me" measured a respondent's sense of similarity toward other supply chain groups regarding forest sustainability. Harman's single factor test [46] for common method variance was used to test for method bias.

Co-orientation agreement was assessed by testing for statistical differences between owner, contractor, and manufacturer responses. Co-orientation accuracy was determined by testing for statistical differences between one group's prediction of a counterpart's response and the counterpart's actual response. Co-orientation congruency was evaluated by testing for statistical differences between a group's prediction of another group's response to a question and their own response to the same question. Responses to identity items were cross-tabulated by group and tested for statistical differences.

More than $60 \%$ of Virginia's 25.7 million acres (10.4 million ha) are forested and held mostly by thousands of private owners. Real property records containing forest owner contact information are not aggregated at the state level but managed discretely by 95 counties and 39 independent cities. Because of this, cluster sampling was used to choose counties from which forest owners were randomly selected. Independent cities were excluded.

Virginia's 95 counties were stratified into five geographic regions using the United States Department of Agriculture Forest Service's Forest Inventory and Analysis program boundaries (Figure 1). At least three counties were randomly chosen in each stratum to ensure the proportion of summed county land reflected the proportion that region contributes to Virginia's total land area. Twenty-four counties were sampled and real property records acquired from county governments. Sixty-three owners of private land greater than or equal to 10 acres ( 4 ha) were randomly selected in each county to create a sample of 1512 participants. A minimum area of 10 acres (4 ha) was selected because certification programs in the U.S.A. typically begin enrollment at this level.

Nine-hundred and seventy-nine Virginia logging contractors were identified using Virginia Department of Forestry's (VDOF) code ID registry maintained in compliance with the state's water quality laws. Logging contractors intending to conduct timber harvests must notify the VDOF of 
the location so tracts can be inspected for compliance. Contractors must acquire an identification number which is used each time VDOF is notified of a harvest. Two-hundred and fifty primary wood products manufacturers in Virginia were identified using VDOF's primary wood products manufacturer state registry.

A total of 2741 surveys were mailed to sampled forest owners, logging contractors, and wood products manufacturers. Following Dillman [47], an introductory letter was mailed first. Forest owners also received a pre-addressed sampling-error reduction card. This allowed recipients to opt out of the study if they owned less than 10 acres ( 4 ha) of contiguous forest land. A second mailing included a follow-up letter, the survey, and a self-addressed business reply envelope. Non-respondents received a reminder postcard followed by a replacement instrument. Non-response bias was evaluated by comparing early- (71\%) and late-respondents (29\%) following the assumption that late-respondents are more like non-respondents [48]. Late-respondents returned their surveys after a replacement was received. No descriptive differences were observed between early- and late-respondents. Harman's single factor test for common method variance across all respondent types was less than $40 \%$.

Data were analyzed using non-parametric statistics because assumptions such as continuous data or normal distribution were not met. Ranks were substituted for values and used to test the hypothesis that mean rank distributions were equal. Kruskal-Wallis one-way rank [49] was used to test if there was agreement between owners, contractors, and manufacturers and if one respondent group accurately predicted the response of another. Related-samples Wilcoxon signed rank [50] was used to test for congruency between a group's perspective and their prediction of other groups because the respondents answered the questions twice (i.e., once as themselves and once as the other party). Mean scores and standard errors were calculated to depict central tendency and distribution. The Pearson $\chi^{2}$ test [51] was used to assess significant differences between expected and observed outcomes across similarity measures cross-tabulated by respondent group. Statistical tests used $\alpha=0.05$ to determine significance.

\section{Results}

Surveys were successfully delivered to 2661 of the 2741 private forest owners, logging contractors, and wood products manufacturers with an overall response rate of $32.5 \%$. Five hundred and eight forest owners returned a survey. One hundred and twenty eight owners noted they owned less than 10 acres (4 ha) of contiguous forest leaving 380 usable responses for a $28.6 \%$ adjusted response rate. Of the 398 logging contractors that returned surveys, 40 noted they were not the business owner and four were no longer in business resulting in a 38.8\% adjusted response rate. Twenty-five of the 91 manufacturers that returned surveys were no longer in business leaving 66 usable surveys for a $29.3 \%$ adjusted response rate.

Forest owners had 106,957 acres (43,284 ha) with an average parcel size of 289 acres (117 ha). Slightly more than $50 \%$ of forest owners had harvested timber before and $4 \%$ owned certified forest land. Logging contractors hauled an average of 23.3 loads per week. Nineteen percent of the contractors had conducted operations on certified land and the same percent had previously received mill requests to supply certified wood. Annual average green metric tons and million board feet among manufacturers totaled nearly 2.1 million and 31.5 million, respectively. Seventy-nine percent of businesses were sawmills, while pulp and paper and specialty chip, composite, and veneer businesses made up the remaining 21\%. Twenty-nine percent of the businesses were enrolled in a certification program.

Manufacturer perspectives on forest certification were less favorable when compared to that of forest owners and logging contractors (Table 1). The exception was that their understanding of the certification process did not differ significantly from contractors but statistically exceeded owners who tended to know less about how to certify forestland. Owner and contractor responses tended to be positive and mostly consistent, whereas manufacturer responses were more variable. Owners were slightly more likely than contractors to believe that forest certification provides economic benefits, whereas contractors believed they understood the certification process better. 
Table 1. Agreement between the average response among private forest owners, logging contractors, and wood products manufacturers to four survey items measuring perspectives about forest certification.

\begin{tabular}{|c|c|c|c|c|}
\hline \multirow[b]{2}{*}{$\begin{array}{l}\text { Supply } \\
\text { chain } \\
\text { group }\end{array}$} & \multicolumn{4}{|c|}{$\begin{array}{c}\text { Agreement } \\
\text { (Scale: } 1-5 ; 1 \text { Is "Strongly Disagree" and } 5 \text { Is "Strongly Agree") }\end{array}$} \\
\hline & $\begin{array}{c}\text { Provides economic } \\
\text { benefits } \\
n=749 \\
\text { statistic }=25.42 *\end{array}$ & $\begin{array}{c}\text { Improves their } \\
\text { image } \\
n=751 \\
\text { statistic }=18.54 \text { * }\end{array}$ & $\begin{array}{c}\text { Positively impacts } \\
\text { forestry } \\
n=750 \\
\text { statistic }=25.45 *\end{array}$ & $\begin{array}{c}\text { Understand how to } \\
\text { certify } \\
n=749 \\
\text { statistic }=80.04 \text { * }\end{array}$ \\
\hline $\begin{array}{l}\text { Private } \\
\text { forest } \\
\text { owners }\end{array}$ & $\begin{array}{l}3.17^{\mathrm{a}} \\
(0.04)\end{array}$ & $\begin{array}{l}3.17^{\mathrm{a}} \\
(0.05)\end{array}$ & $\begin{array}{l}3.18^{\mathrm{a}} \\
(0.04)\end{array}$ & $\begin{array}{l}2.57^{\mathrm{a}} \\
(0.05)\end{array}$ \\
\hline $\begin{array}{l}\text { Logging } \\
\text { contractors }\end{array}$ & $\begin{array}{l}3.10^{\mathrm{b}} \\
(0.05)\end{array}$ & $\begin{array}{l}3.23^{\mathrm{a}} \\
(0.03)\end{array}$ & $\begin{array}{l}3.15^{\mathrm{a}} \\
(0.06)\end{array}$ & $\begin{array}{l}3.25^{\mathrm{b}} \\
(0.06)\end{array}$ \\
\hline $\begin{array}{c}\text { Wood } \\
\text { products } \\
\text { manufacturers }\end{array}$ & $\begin{array}{l}2.57^{\mathrm{c}} \\
(0.12)\end{array}$ & $\begin{array}{l}2.70^{\mathrm{b}} \\
(0.13)\end{array}$ & $\begin{array}{l}2.50^{b} \\
(0.13)\end{array}$ & $\begin{array}{l}2.94^{b} \\
(0.15)\end{array}$ \\
\hline
\end{tabular}

* Significant Kruskal-Wallis test statistic; scores in each column with the same letter are not significantly different at $p \leq 0.05$.

Forest owners tended to predict significantly lower responses for contractors when compared to what they actually reported except for their beliefs on the economic benefits of forest certification (Table 2). Conversely, owners mostly over-predicted manufacturer responses with only their estimate of understanding being statistically similar. Contractors accurately estimated forest owner responses for all but their understanding of the certification process, which was predicted to be slightly higher than what they actually reported. On the other hand, contractors predicted statistically higher average responses for manufactures for all but understanding. Manufacturers under-predicted owner responses only in terms of economic benefits and impacts to forestry, but did the same for contractors across all responses.

Table 2. Accuracy between the average prediction of responses among private forest owners, logging contractors, and wood products manufacturers about each other and the actual average responses to four survey instrument items measuring perspectives about forest certification.

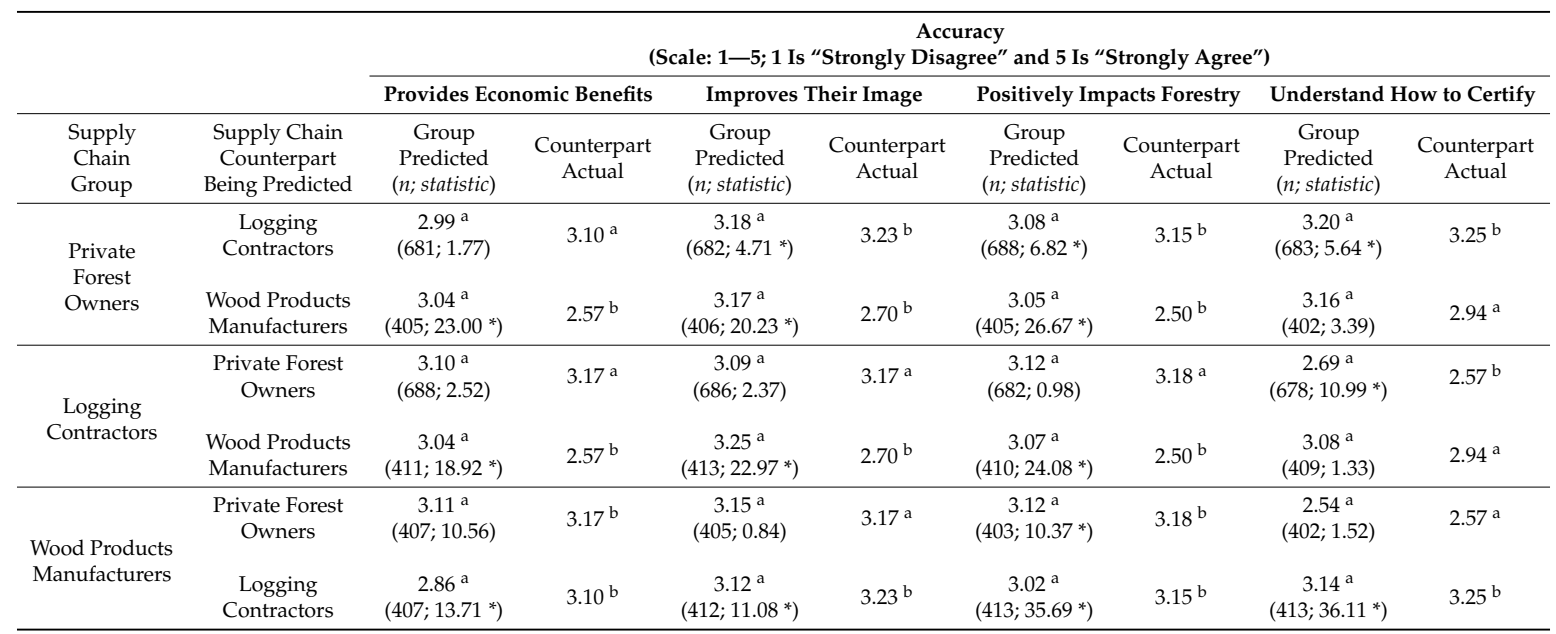

* Significant Kruskal-Wallis test statistic; scores in each predicted/actual pair with the same letter are not significantly different at $p \leq 0.05$.

Forest owners believed contractors would not agree with them about economic benefits and impacts to forestry, but that their understanding would be better (Table 3). They also believed 
that manufacturers would better understand the certification process. Contractors believed owner responses would be lower than theirs for all items and thought manufacturers would more be more likely than them to believe there are economic benefits, but that they would understand the process better. Manufacturers believed owners would respond more positively about benefits to their image and the forestry sector than they did, but that they would understand forest certification better. At the same time, they believed contractors would understand it better than them and be more likely to believe it positively impacts forestry.

Table 3. Congruency between the average prediction of responses among private forest owners, logging contractors, and wood products manufacturers about each other and their own average responses to four survey items measuring perspectives about forest certification.

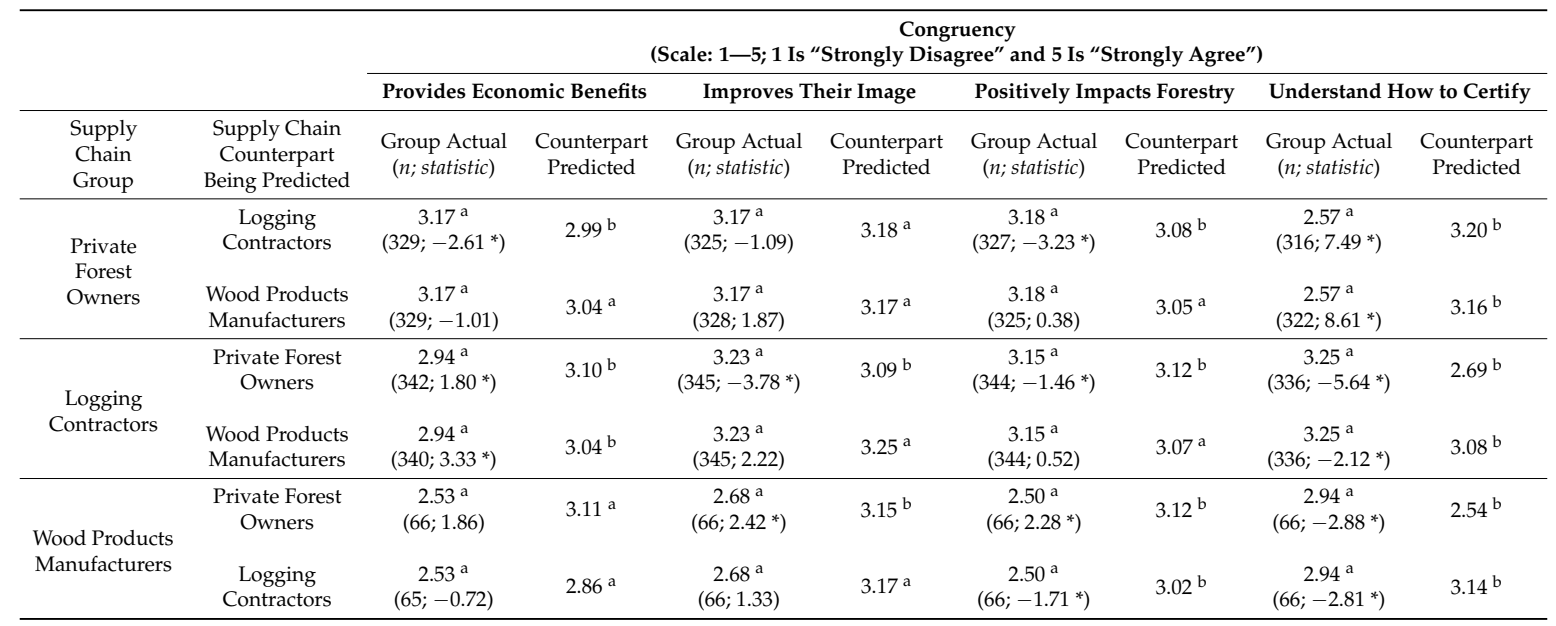

* Significant Wilcoxon signed rank statistic; scores in each actual/predicted pair with the same letter are not significantly different at $p \leq 0.05$.

Logging contractors were more likely to feel they shared a high level of identity toward owners, while manufacturers were more likely to report only moderate levels (Table 4). Somewhat differently, manufacturers were more likely to report a high sense of shared identity with contractors, whereas owners reported mostly a low sense of shared identity with the same group. Likewise, contractors were more inclined to share either a high or moderate sense of identity with manufacturers and owners were most likely to report low levels of shared identity with manufacturers, though the distribution of their responses about manufacturers was not as skewed compared to their responses about contractors.

Table 4. Cross-tabulation of responses among private forest owners, logging contractors, and wood products manufacturers to a survey item measuring their level of shared identity with each other regarding forest sustainability. The survey item scale is three-point ranging from "not at all like me" to "a lot like me".

\begin{tabular}{|c|c|c|c|c|c|}
\hline \multirow[b]{2}{*}{$\begin{array}{l}\text { Supply Chain } \\
\text { Group }\end{array}$} & \multirow{2}{*}{$\begin{array}{l}\text { Counterpart Group } \\
\text { toward Which } \\
\text { Identity Is Assessed }\end{array}$} & \multirow[b]{2}{*}{ Cross-Tabulation } & \multicolumn{3}{|c|}{ Identity } \\
\hline & & & Low & Medium & High \\
\hline \multirow{4}{*}{$\begin{array}{c}\text { Logging } \\
\text { Contractors } \\
\text { Wood } \\
\text { Products } \\
\text { Manufacturers }\end{array}$} & \multirow{3}{*}{$\begin{array}{c}\text { Private Forest } \\
\text { Owners }\end{array}$} & Number & 68 & 115 & 148 \\
\hline & & (Expected; Adjusted Residual) & $(68 ; 1.0)$ & $(128.4 ;-3.7)$ & $(137.6 ; 2.9)$ \\
\hline & & $\begin{array}{c}\text { Number } \\
\text { (Expected; Adjusted Residual) }\end{array}$ & $\begin{array}{c}10 \\
(13.0 ;-1.0)\end{array}$ & $\begin{array}{c}39 \\
(25.6 ; 3.7)\end{array}$ & $\begin{array}{c}17 \\
(27.4 ;-2.9)\end{array}$ \\
\hline & & & $\begin{array}{r}\chi^{2}= \\
\text { a zero ce }\end{array}$ & $\begin{array}{l}.98^{\mathrm{a}}, d f=2 \\
0.0 \%) \text { expec }\end{array}$ & $\begin{array}{l}0.00 \\
\text { count }<5\end{array}$ \\
\hline
\end{tabular}


Table 4. Cont.

\begin{tabular}{|c|c|c|c|c|c|}
\hline \multirow{2}{*}{$\begin{array}{l}\text { Supply Chain } \\
\text { Group }\end{array}$} & \multirow{2}{*}{$\begin{array}{l}\text { Counterpart Group } \\
\text { toward Which } \\
\text { Identity Is Assessed }\end{array}$} & \multirow[b]{2}{*}{ Cross-Tabulation } & \multicolumn{3}{|c|}{ Identity } \\
\hline & & & Low & Medium & High \\
\hline \multirow{3}{*}{$\begin{array}{l}\text { Private Forest } \\
\text { Owners } \\
\text { Wood } \\
\text { Products } \\
\text { Manufacturers }\end{array}$} & \multirow{3}{*}{ Logging Contractors } & $\begin{array}{c}\text { Number } \\
\text { (Expected; Adjusted Residual) }\end{array}$ & $\begin{array}{c}140 \\
(124.0 ; 4.4)\end{array}$ & $\begin{array}{c}110 \\
(109.9 ; 0.0)\end{array}$ & $\begin{array}{c}78 \\
(94.1 ;-4.8)\end{array}$ \\
\hline & & $\begin{array}{c}\text { Number } \\
\text { (Expected; Adjusted Residual) }\end{array}$ & $\begin{array}{c}9 \\
(9 ; 25.0 ;-4.4)\end{array}$ & $\begin{array}{c}22 \\
(22.1 ; 0.0)\end{array}$ & $\begin{array}{c}35 \\
(18.9 ; 4.8)\end{array}$ \\
\hline & & & \multicolumn{3}{|c|}{$\begin{array}{c}\chi^{2}=28.65^{\mathrm{a}}, d f=2, p<0.00 \\
\text { a zero cells }(0.0 \%) \text { expected count }<5\end{array}$} \\
\hline \multirow[t]{2}{*}{$\begin{array}{l}\text { Private Forest } \\
\text { Owners }\end{array}$} & $\begin{array}{l}\text { Wood Products } \\
\text { Manufacturers }\end{array}$ & $\begin{array}{c}\text { Number } \\
\text { (Expected; Adjusted Residual) } \\
\text { Number } \\
\text { (Expected; Adjusted Residual) }\end{array}$ & $\begin{array}{c}85 \\
(107.7 ;-3.8) \\
130 \\
(107.3 ; 3.8)\end{array}$ & $\begin{array}{c}110 \\
(113.7 ;-0.6) \\
117 \\
(113.3 ; 0.6)\end{array}$ & $\begin{array}{c}134 \\
(107.7 ; 4.4) \\
81 \\
(107.3 ;-4.4)\end{array}$ \\
\hline & & & \multicolumn{3}{|c|}{$\begin{array}{c}\chi^{2}=22.70 \text { a }, d f=2, p<0.00 \\
\text { a zero cells }(0.0 \%) \text { expected count }<5\end{array}$} \\
\hline
\end{tabular}

\section{Discussion}

In general, wood products manufacturers viewed forest certification negatively when compared to forest owners and contractors. This is not surprising because financial benefits and certified raw material have not come easy for many manufacturers [25]. As a result, enthusiasm among them is generally low and widespread industry participation remains limited [11]. In this study, fewer than one out of three manufacturers were enrolled in a forest certification system, but their responses were also highly variable pointing to a range of perspectives and potential separation between manufacturer types. Ultimately, the array of manufacturer perspectives coupled with their overall negative leaning indicates certification is not generally appealing though some participate and find value in it.

Manufacturer participation in forest certification is likely related in large part to whether it provides marketplace benefits and can be justified as a competitive and culturally acceptable business strategy [52]. Highly mechanized, large-scale firms are generally low in number but highly visible in the public eye and use certification to build reputation and consumer confidence [53]. These companies promote certification as part of an internal culture focused on company image and external market share among specialized customers that demand sustainably sourced materials for their product lines [33]. On the other hand, most other manufacturers are less specialized and visible in the marketplace and depend more regularly on general consumers. Ultimately, they may not be as compelled by or capable of enrolling in forest certification because they do not see the value in it, cannot afford it, or the benefits and processes are not clear [11,22].

Congruent with their perspectives and sense of similarity, manufacturers in this study believed contractors would share their viewpoint but owners would not. Yet perspectives among forest owners and contractors were almost entirely positive and largely in a state of true consensus. The strong sense of shared identity manufacturers reported toward logging contractors may have played a role in the discrepancy. However, contractors generally identified and agreed with owners and accurately predicted their perspectives. Interestingly, both owners and contractors mistakenly predicted that understanding of the forest certification process would be better among manufacturers.

Consistency and alignment among manufacturers could change if forest certification opportunities improve for products across all operational scales. Such a shift would help increase awareness and interest among owners and contractors, eventually leading to additional involvement in forest certification. This outcome could help increase and standardize certified supply through inclusive entrepreneurial networks defined by both social responsibility and financial gains. However, a significant challenge for forest certification is that most manufacturers are deterred by the steep costs and hesitant to invest because of market uncertainty [6]. 
Without manufacturer participation, it is unlikely that small-scale owners who harvest irregularly [19] and contractors who operate on thin margins [12] will network and supply certified raw material, let alone engage in nuanced business strategies such as using certification to manage their image or improve market access [22]. As a result, forest certification may encounter a situation where increased demand for certified products could mitigate concerns related to costs and uncertainty, but consistent supply becomes more difficult to find. Still, rising demand may increase the price for certified wood and compel producers to take on the extra costs and administrative burden to produce it. In light of this study, the possibility of this paradox bolsters the call by Visseren-Hamakers and Pattberg [26] " ... to critically reflect on the real and measurable added value of certification for the sustainability transition (p. 25)."

Forest owner perspectives on certification were slightly positive. Contractors were less optimistic than forest owners in terms of economic benefits, but reported a higher level of understanding. Owner predictions about contractors were not as accurate or congruent as contractor predictions about them, but interestingly owner predictions aligned slightly better with manufacturers. Nevertheless, contractors were more likely to agree with owners overall. This was somewhat unexpected because of the shared identity between manufacturers and contractors, yet when it comes to forest certification perspectives were negative among manufacturers and they erroneously believed contractors would feel the same.

Though not overwhelming, the alignment of owner and contractor perspectives suggests they share entrepreneurial orientation in true consensus when it comes to forest certification. Moreover, contractors appear to be in a unique place to lead widespread networking by incorporating market-based forest certification communication, education, and management into their services. Their distinction from manufacturers and false consensus indicates that in their role as a potential broker of certified raw material between forest owners and manufacturers, contractors tend to pivot more toward those who supply forest products rather than buy them. Thus they could serve as an informed group that conveys management standards and certification opportunities to owners who are broadly distributed and largely uninformed, but more often than not optimistic.

Even though results underscore consensus between owners and contractors, the possibilities related to forest certification may go unrealized unless more manufacturers demand it and offer strategic profit and consistent market share opportunities [54]. Without these signals, most owners and contractors are unlikely to proactively involve themselves in forest certification even if they think it is the right thing to do [52]. If they do despite the absence of useful downstream market incentives, it may be that the positive orientation of owners and contractors begins to change and the false consensus between contractors and manufacturers becomes true. The issue is that many manufacturers currently see no need to certify and note supply is generally difficult to obtain. Therefore, forest certification and its benefits hinges on more than consumer image which matters to some but not all.

Growth in product demand and prices on the retail side, in addition to clear evidence of positive impacts of certification to forest productivity and operations are also necessary. In agreement, a recent review on global forest certification trends indicated that in developed countries market demand was one of the significant drivers of certification together with stable economies, social pressure, and habitat type [55]. Changes in demographics, education level, cultural diversity, and access to information among consumers has increased forest product market fragmentation and market niches in Virginia [56]. A gradual increase in sectors such as home construction and remodeling could increase demand for local wood products that are sheltered from international competition because of marketing and distribution characteristics [57]. Consumption of novel products may also increase [56], and the greater value assigned by consumers to environmental matters may drive demand for certified wood products.

\section{Conclusions}

Research hypotheses for this study were that forest certification perspectives among private forest owners, logging contractors, and wood products manufacturers would be co-oriented and that 
they would share a sense of identity. Results suggest that forest owners and logging contractors are generally aligned when compared to manufacturers, but they are more numerous and share the common objective of sourcing raw material. This may be the chief driver of the differences in this study, but while forest owners and contractors may be poised to engage in forest certification they also need incentives to act. Without market signals from manufacturers, most forest owners and contractors will likely stay uninformed or ambivalent.

If demand for certified wood products increases, additional supply would need to come by way of smaller forests, diverse logging contractors, and manufacturers of all kinds. Growth likely will remain slow or non-existent unless these value chain participants clearly see a favorable balance between costs and benefits. Owner and contractor alignment points to the potential for entrepreneurial networking if manufacturers can invest not only generally in forest certification for purposes of image control but more specifically in the financial and cultural infrastructure needed to broaden supply chain participation. Market share could provide a useful foundation, but a rapid push to increase participation without financial stability could backfire. Awareness and understanding may improve with time but notable changes in current rates of participation cannot be expected if ambiguity and uncertainty remain. Thus, tradeoffs are often less than compelling for many even when they are familiar with forest certification. Inclusive networks could alter the cost and benefit balance by aligning entrepreneurial strategies and building stronger supply chain ties through programs such as owner and contractor assistance and long-term contracting [29,31]. Also important are contractor-specific strategies that leverage their supply chain position. All can help refine a forest certification supply chain whose function should be defined by profitability and predictable markets with well-oriented entrepreneurial aims.

Acknowledgments: The authors thank the Virginia Department of Forestry for its support.

Author Contributions: John Munsell, Scott Barrett, Brian Bond, and Jennifer Gagnon designed and conducted the research. John Munsell and Adrian Ares analyzed the data and all authors wrote the manuscript.

Conflicts of Interest: The authors declare no conflict of interest.

\section{References}

1. Vogt, K.A.; Larson, B.C.; Gordon, J.C.; Vogt, D.J.; Fanzeres, A. Forest Certification: Roots, Issues, Challenges, and Benefits; CRC Press: New York, NY, USA, 1999; p. 400.

2. Rametsteiner, E.; Simula, M. Forest certification-An instrument to promote sustainable forest management. J. Env. Manag. 2003, 67, 87-98. [CrossRef]

3. Nussbaum, R.; Simula, M. The Forest Certification Handbook, 2nd ed.; Earth Scan Publication Ltd.: London, UK, 2005; 320p.

4. Ahn, Y.H.; Pierce, A.R. Green construction: Contractor experiences, expectations, and perceptions. J. Green Buld. 2007, 2, 106-122. [CrossRef]

5. Irland, L.C. Developing markets for certified wood products: Greening the supply chain for construction materials. J. Ind. Eco. 2007, 11, 201-216. [CrossRef]

6. Espinoza, O.; Buehlmann, U.; Smith, R. Forest certification and green building standards: Overview and use in the U.S. hardwood industry. J. Clean. Prod. 2012, 33, 30-41. [CrossRef]

7. Estep, G.D.; DeVallance, D.B.; Lacombe, D.J. Analysis of certified wood production use in commercial LEED green building projects. Wood Fib. Sci. 2015, 47, 270-282.

8. Lowe, L.; Brogan, S.; McClure, N.; Nowak, J.; Oates, B.; Preston, D.; Tucker, W. Forest certification programs: Status and recommendations in the south-A report of the southern group of state foresters. 2011. Available online: http:/ / www.southernforests.org/resources/publications/SGSF\%20Forest $\% 20$ Certification\%20Report\% 20r1.pdf (accessed on 15 April 2015).

9. Vlosky, R.P.; Gazo, R.; Cassens, D. Certification involvement by selected United States value-added solid wood products sectors. Wood Fib. Sci. 2007, 35, 560-569.

10. Leahy, J.E.; Kilgore, M.A.; Hibbard, C.M.; Donnay, J.S. Family forest landowners' interest in and perceptions of forest certification: Focus group findings from Minnesota. Nor. J. Appl. For. 2008, 25, 73-81. 
11. Bond, B.; Lyon, S.; Munsell, J.F.; Barrett, S.M.; Gagnon, J. Perceptions of Virginia's primary forest products manufacturers regarding forest certification. For. Prod. J. 2014, 64, 242-249. [CrossRef]

12. Germain, R.H.; Bick, S.; Kelly, M.C.; Benjamin, J.G.; Farrand, W. A case study of three high-performing contract loggers with distinct harvest systems: Are they thriving, striving, or just surviving? For. Prod. J. 2016, 66, 97-105. [CrossRef]

13. Butler, B.J.; Hwes, J.H.; Dickinson, B.J.; Andrejczk, K.; Butler, S.M.; Markowski-Lindsay, M. USDA Forest Service National Woodland Owner Survey: National, Regional, and State Statistics for Family Forest and Woodland Ownerships with More Than 10+ Acres, 2011-2013; Res. Bull. NRS-99; U.S. Department of Agriculture, Forest Service, Northern Research Station: Newtown Square, PA, USA, 2016; p. 39.

14. Bensel, T. Promoting certified sustainable forestry on private woodlots in north-western Pennsylvania: Challenges and opportunities. Local Environ. 2001, 6, 257-278. [CrossRef]

15. Rickenbach, M.G. Forest certification of small ownerships: Some practical challenges. J. For. 2002, 100, 43-47.

16. Overdevest, C.; Rickenbach, M.G. Forest certification and institutional governance: An empirical study of Forest Stewardship Council certification holders in the United States. For. Policy Econ. 2006, 9, 93-102. [CrossRef]

17. Kilgore, M.A.; Greene, J.L.; Jacobson, M.G.; Straka, T.J.; Daniels, S.E. The influence of financial incentive programs in promoting sustainable forestry on the nation's family forests. J. For. 2007, 105, 184-191.

18. Hayward, J.; Vertinsky, I. High expectation, unexpected benefits: What managers and owners think of certification. J. For. 1999, 97, 13-17.

19. Butler, B.J. Family Forest Owners of the United States, 2006; Gen. Tech. Rep. NRS-27; U.S. Department of Agriculture, Forest Service, Northern Research Station: Newtown Square, PA, USA, 2008; p. 72.

20. Cubbage, F.; Moore, S.; Henderson, T.; Araujo, M. Costs and benefits of forest certification in the Americas. In Natural Resources: Management, Economic Development and Protection; Pauling, J., Ed.; Nova Science: Hauppauge, NY, USA, 2009; pp. 155-183.

21. Rickenbach, M.G.; Steele, T.W. Logging firms, nonindustrial private forests, and forest parcelization: Evidence of firm specialization and its impact on sustainable timber supply. Can. J. For. Res. 2006, 36, 186-194. [CrossRef]

22. Forrer, J.; Mo, K. From certification to supply chain strategy: An analytical framework for enhancing tropical forest governance. Organ. Environ. 2013, 26, 260-280. [CrossRef]

23. Moore, S.E.; Cubbage, F.; Eicheldinger, C. Impacts of forest stewardship council (FSC) and sustainable forestry initiative (SFI) forest certification in North America. J. For. 2012, 110, 79-88. [CrossRef]

24. Hansen, E.; Fletcher, R.; Cashore, B.; McDermott, C. Forest Certification in North America; Oregon State University, Extension Service: Corvallis, OR, USA, 2006.

25. Montague, I.B. Understanding Chain-of-Custody Certification in the Appalachian Hardwood Region: Primary Manufacturers' Practices and Perceptions, Proceedings of the 17th Central Hardwood Forest Conference, Lexington, KY, USA, 5-7 April 2010; Fei, S., Lhotka, J.M., Stringer, J.W., Gottschalk, K.W., Miller, G.W., Eds.; Gen. Tech. Rep. NRS-P-78; U.S. Department of Agriculture, Forest Service, Northern Research Station: Newtown Square, PA, USA, 2011; pp. 607-616.

26. Visseren-Hamakers, I.J.; Pattberg, P. We can't see the forest for the trees: The environmental impact of global forest certification is unknown. GAIA Ecol. Perspect. Sci. Soc. 2013, 22, 25-28.

27. Chaplin-Kramer, R.; Jonell, M.; Guerry, A.; Lambin, E.F.; Morgan, A.J.; Pennington, D.; Smith, N.; Franch, J.A.; Polasky, S. Ecosystem service information to benefit sustainability standards for commodity supply chains. Ann. N. Y. Acad. Sci. 2015, 1355, 77-97. [CrossRef] [PubMed]

28. Johansson, J. Why do forest companies change their CSR strategies? Responses to market demands and public regulation through dual certification. J. Environ. Plan. Mane. 2014, 57, 349-368. [CrossRef]

29. Carroll, A.B. Corporate social responsibility: The centerpiece of competing and complementary frameworks. Organ. Dyn. 2015, 4, 87-96. [CrossRef]

30. Grunert, K.G.; Fruensgaard Jeppesen, L.; Risom Jespersen, K.; Sonne, A.M.; Hansen, K.; Tondsen, T.; Young, J.A. Market orientation of value chains: A conceptual framework based on four case studies from the food industry. Eur. J. Market. 2005, 39, 428-455. [CrossRef]

31. Wagner, M. Corporate social performance and innovation with high social benefits: A quantitative analysis. J. Bus. Ethics 2010, 94, 581-594. [CrossRef]

32. Galaskiewicz, J. Studying supply chains from a social network perspective. J. Supply Chain Manag. 2011, 47, 4-8. [CrossRef] 
33. Sen, S.; Bhattacharya, C.B. Does doing good always lead to doing better? Consumer reactions to corporate social responsibility. J. Market. Res. 2001, 38, 225-243. [CrossRef]

34. Aguinis, H.; Glavas, A. What we know and don't know about corporate social responsibility: A review and research agenda. J. Manag. 2012, 38, 932-968. [CrossRef]

35. Newcomb, M.T. An approach to the study of communicative acts. Psychol. Rev. 1953, 60, 393-404. [CrossRef] [PubMed]

36. McLeod, J.M.; Chaffee, S.H. Interpersonal approaches to communication research. Am. Behav. Sci. 1973, 16, 469-499. [CrossRef]

37. Leong, K.M.; McComas, K.A.; Decker, D.J. Formative co-orientation research: A tool to assist with environmental decision making. Environ. Commun. 2008, 2, 257-273. [CrossRef]

38. Seltzer, T.; Mitrook, M. Two sides to every story: Using co-orientation to measure direct and meta-perspectives of both parties in organization-public relationships. Pub. Rel. J. 2009, 3, 1-24.

39. Scheff, T. Toward a sociological model of consensus. Am. Soc. Rev. 1967, 32, 32-46. [CrossRef]

40. Dozier, D.; Ehling, W.P. Evaluation of public relation programs: What the literature tell us about their effects. In Excellence in Public Relations and Communication Management; Gruning, J.E., Ed.; Lawrence Erlbaum Associates: Hillsdale, NJ, USA, 1992; pp. 327-347.

41. Connelly, N.A.; Knuth, B.A. Using the co-orientation model to compare community leaders' and local residents' views about Hudson River ecosystem restoration. Soc. Natur. Resour. 2002, 15, 933-948. [CrossRef]

42. Carrozino-Lyon, A.L.; McMullin, S.L.; Parkhurst, J.A. Co-orientation of state wildlife agency personnel and wildlife management area stakeholders regarding wildlife habitat management activities in Virginia. Environ. Commun. 2014, 8, 508-528. [CrossRef]

43. Von Kutzchenback, M.; Brønn, C. Communicating sustainable development initiatives: Applying co-orientation to forest management certification. J. Commun. Manag. 2006, 10, 304-322. [CrossRef]

44. Lumpkin, G.T.; Dess, G.G. Clarifying the entrepreneurial orientation construct and linking it to performance. Acad. Manag. Rev. 1996, 21, 135-172.

45. Wiklund, J.; Shepherd, D. Entrepreneurial orientation and small business performance: A configurational approach. J. Bus. Vent. 2005, 20, 71-91. [CrossRef]

46. Harman, H.H. Modern Factor Analysis, 1st ed.; University of Chicago Press: Chicago, IL, USA, 1967; 474p.

47. Dillman, D.A. Mail and Internet Surveys: The Tailored Design Method; John Wiley \& Sons: New York, NY, USA, 2000; Volume 2, 464p.

48. Groves, R.M.; Dillman, D.A.; Eltinge, J.L.; Little, R.J. Survey Nonresponse; John Wiley \& Sons: New York, NY, USA, 2002; 500p.

49. Kruskal, W.; Wallis, W.A. Use of ranks in one-criterion variance analysis. J. Amer. Stat. Assoc. 1952, 47, 583-621. [CrossRef]

50. Wilcoxon, F. Individual comparisons by ranking methods. Biom. Bull. 1945, 1, 80-83. [CrossRef]

51. Plackett, R.L. Karl Pearson and the Chi-squared test. Int. Stat. Rev. 1983, 51, 59-72. [CrossRef]

52. Hemingway, C.A.; Maclagan, P.W. Managers' personal values as drivers of corporate social responsibility. J. Bus. Ethics 2004, 50, 33-34. [CrossRef]

53. Lister, J. Corporate Social Responsibility and the State: International Approaches to Forest Co-regulation; UBC Press: Vancouver, BC, Canada, 2011; 304p.

54. Menguc, B.; Ozanne, L.K. Challenges of the "green imperative": A natural resource-based approach to the environmental orientation-business performance relationship. J. Bus. Res. 2005, 58, 430-438. [CrossRef]

55. Sargent, M.A. Global Drivers of Forest Certification. Master's Thesis, Nicholas School of the Environment, Duke University, Durham, NC, USA, 2014; p. 35.

56. Rephan, T.J. The Economic Impact of Virginia's Agriculture and Forest Industries. Master's Thesis, Weldon Cooper Center for Public Service, University of Virginia, Charlottesville, VA, USA, 2017; p. 61.

57. Luppold, W.G.; Bumgardner, M.S. The wood household furniture and kitchen cabinet industries: A contrast in fortune. For. Prod. J. 2009, 59, 93-99. [CrossRef]

(C) 2017 by the authors. Licensee MDPI, Basel, Switzerland. This article is an open access article distributed under the terms and conditions of the Creative Commons Attribution (CC BY) license (http:/ / creativecommons.org/licenses/by/4.0/). 